\section{Blood plasma versus serum: which is right for sampling circulating membrane microvesicles in human subjects?}

We have read with great interest the article by Kato and colleagues regarding the 'Apoptosis-derived membrane vesicles drive the cGAS-STING pathway and enhance type I IFN production in systemic lupus erythematosus'. ${ }^{1}$ However, we are concerned that the authors studied exclusively blood serum, that is, all blood samples from their patients with lupus and healthy controls were coagulated ex vivo before analysis.

At least three major changes can occur to the population of membrane microvesicles (MVs) during coagulation in a test tube. First, a subset of circulating MVs participate in, and become consumed by, clotting. For example, studies from our group and others indicated that over half of the total membrane MVs in blood plasma ${ }^{2}$ or the in vitro generated $\mathrm{MVs}^{34}$ display phosphatidylserine (PS) on their surface. PS-positive MVs are procoagulant relative to those that are PS negative ${ }^{235}$ because PS forms a catalytic membrane surface that promotes assembly and catalysis of coagulation factor complexes. ${ }^{36}$ It is especially true for apoptotic MVs, ${ }^{3578}$ since membrane surface exposure of PS is a hallmark of cell apoptosis. ${ }^{9}$ Thus, PS-positive MVs could be preferentially involved in clot formation in the sampling tube when blood is drawn without anticoagulants. The remaining MVs in the serum tube may not be representative of the original population of MVs that were in the circulation. ${ }^{4}$

A second change during clotting ex vivo is the generation of new population of MVs that were not originally presented in the circulation. Platelets become activated during clot formation in a test tube and release artificially generated MVs in vitro during the sampling process. ${ }^{10}$ Platelet-derived MVs generated in the sample tube may account for $50 \%$ of the MVs in serum. ${ }^{10}$ Other cells in blood may also release MVs during the ex vivo clotting. These 'artificial' MVs in serum cannot represent the pathophysiological condition of the circulating blood in patients with lupus and healthy controls.

A third change during clotting is the possible cleavage of proteins on MVs by proteases, that is, thrombin, generated during the coagulation cascade. This problem has not been widely studied in MV research field, but it is known in other fields. For example, thrombin digests apolipoprotein-B into fragments, ${ }^{11}$ and the 'intact' lipoproteins are isolated from plasma, not serum.

In our opinion, blood plasma ${ }^{12}$ prepared in the presence of anticoagulants - should be used in MV research because it avoids consumption of the 'original circulating' MVs, and production of the 'artificial' MVs, as well as exposure to proteases, during clotting ex vivo in the serum sample tubes. But the study results with serum, as used by Kato et al and other groups, should be confirmed with blood plasma. Artefacts caused by the clotting of blood in a test tube may largely affect results and conclusions of any studies of circulating membrane MVs in clinical translational investigations. Therefore, blood sampling of the circulating membrane MVs in human subjects is an important point that needs to be clarified among the investigators who conduct clinical translational researches.
Ming-Lin Liu $\odot,^{1,2}$ Victoria P Werth, ${ }^{1,2}$ Kevin Jon Williams ${ }^{3}$

${ }^{1}$ Department of Dermatology, Perelman School of Medicine, University of Pennsylvania, Philadelphia, Pennsylvania, USA

${ }^{2}$ Corporal Michael J Crescenz VAMC, Philadelphia, PA, USA

${ }^{3}$ Section of Endocrinology, Department of Medicine, Lewis Katz School of Medicine, Temple University, Philadelphia, Pennsylvania, USA

Correspondence to Dr Ming-Lin Liu, University of Pennsylvania, Philadelphia, PA 19104, USA; lium1@pennmedicine.upenn.edu

Contributors MLL conceived the study. MLL, VPW and KJW wrote/drafted and finalised the paper. All authors read and approved the final manuscript.

Funding This work was supported by Lupus Research Alliance (416805, to MLL) and NIH R21AI144838 (to MLL), the Veterans Affairs Merit Review Award (to VPW).

Competing interests None declared.

Patient consent for publication Not required.

Provenance and peer review Not commissioned; internally peer reviewed.

(c) Author(s) (or their employer(s)) 2020. No commercial re-use. See rights and permissions. Published by BMJ.

$$
\text { Check for updates }
$$

To cite Liu M-L, Werth VP, Williams KJ. Ann Rheum Dis 2020;79:e73.

Received 8 April 2019

Accepted 11 April 2019

Published Online First 20 April 2019

Ann Rheum Dis 2020;79:e73. doi:10.1136/annrheumdis-2019-215505

\section{ORCID iD}

Ming-Lin Liu http://orcid.org/0000-0001-8827-2024

\section{REFERENCES}

1 Kato Y, Park J, Takamatsu H, et al. Apoptosis-derived membrane vesicles drive the CGAS-STING pathway and enhance type I IFN production in systemic lupus erythematosus. Ann Rheum Dis 2018;77:1507--2015.

2 Shet AS, Aras 0, Gupta K, et al. Sickle blood contains tissue factor-positive microparticles derived from endothelial cells and monocytes. Blood 2003; 102:2678-83.

3 Liu M-L, Reilly MP, Casasanto P, et al. Cholesterol enrichment of human monocyte/ macrophages induces surface exposure of phosphatidylserine and the release of biologically-active tissue factor-positive microvesicles. Arterioscler Thromb Vasc Biol 2007:27:430-5.

4 Latham SL, Tiberti N, Gokoolparsadh N, et al. Immuno-analysis of microparticles: probing at the limits of detection. Sci Rep 2015;5.

5 Li M, Yu D, Williams KJ, et al. Tobacco smoke induces the generation of procoagulant microvesicles from human monocytes/macrophages. Arterioscler Thromb Vasc Biol 2010;30:1818-24.

6 Zwaal RFA, Comfurius P, Bevers EM. Surface exposure of phosphatidylserine in pathological cells. Cell Mol Life Sci 2005;62:971-88.

7 Casciola-Rosen L, Rosen A, Petri M, et al. Surface blebs on apoptotic cells are sites of enhanced procoagulant activity: implications for coagulation events and antigenic spread in systemic lupus erythematosus. Proc Natl Acad Sci U S A 1996;93:1624-9.

8 Stampfuss JJ, Censarek P, Bein D, et al. Membrane environment rather than tissue factor expression determines thrombin formation triggered by monocytic cells undergoing apoptosis. J Leukoc Biol 2008;83:1379-81.

9 Balasubramanian K, Mirnikjoo B, Schroit AJ. Regulated externalization of phosphatidylserine at the cell surface: implications for apoptosis. J Biol Chem 2007;282:18357-64.

10 Witwer KW, Buzás El, Bemis LT, et al. Standardization of sample collection, isolation and analysis methods in extracellular vesicle research. J Extracell Vesicles 2013;2. doi:10.3402/jev.v2i0.20360

11 Cardin AD, Witt KR, Chao J, et al. Degradation of apolipoprotein B-100 of human plasma low density lipoproteins by tissue and plasma kallikreins. J Biol Chem 1984;259:8522-8.

12 Liu M, Xu H, Bashir M, et al. Proinflammatory microvesicles in patients with cutaneous lupus erythematosus. J Invest Dermatol 2014;134. 